\title{
Selected Thermo-Chemical Biorefining: Evaluation of the Current Trends and Progressions
}

\author{
Great Umenweke ${ }^{1,2 *}$, Joshua Ighalo ${ }^{3,4}$, Modestus Anusi ${ }^{2}$, Blessing Itabana ${ }^{2}$, Lina Ekeh ${ }^{2}$
}

\author{
${ }^{1}$ University of Kentucky, Lexington, USA \\ ${ }^{2}$ Department of Chemical Engineering, Federal University of Technology, Owerri, NIGERIA \\ ${ }^{3}$ Department of Chemical Engineering, University of Ilorin, Ilorin, NIGERIA \\ ${ }^{4}$ Department of Chemical Engineering, Nnamdi Azikiwe University, Awka, NIGERIA \\ *Corresponding Author: umenweke@gmail.com
}

Citation: Umenweke, G., Ighalo, J., Anusi, M., Itabana, B. and Ekeh, L. (2021). Selected Thermo-Chemical Biorefining: Evaluation of the Current Trends and Progressions. European Journal of Sustainable Development Research, 5(2), em0154. https://doi.org/10.21601/ejosdr/10812

\section{ARTICLE INFO}

Received: 10 Nov. 2020

Accepted: 13 Jan. 2021

\begin{abstract}
The review paper embodies the current trends and advancements involved in the transformation of biomass to enhanced products, bioenergy, and chemicals. Some selected chemical process like the slow-fast pyrolysis, catalytic fast pyrolysis, hydrothermal liquefaction, transesterification and lignin valorization by depolymerization are aptly suited for biorefinery processing, and were discussed in this review. The (catalytic) fast pyrolysis and hydrothermal liquefaction are quite similar, but differ in their feedstock preparations, reactor configuration and thermal or energy optimization. The review covers the biomass selection, chemical conversion techniques and most importantly the required heterogeneous catalysts (where applicable). The work further suggests the superiority of dedicated chemicals over drop-in and smart drop-in chemicals, due the complete usage of biomass. Relative to the oil refinery process, biorefining is quite novel and accompanied by its drawbacks. These challenges range from catalyst poisoning and deactivation to energy intensiveness and eventually as being cost-ineffective. The challenge encountered in biorefinery is in the economic feasibility, as it is inferred from this review that the pre-treatment process takes up to about $20 \%$ of the conversion cost. Although the biorefinery plant employ lignocellulosic biomass, but study shows that the use of biomass is largely under-utilized. The solid products/ wastes from pyrolysis for example, can be utilized as source of energy for the process. In the pursuit for sustainability, it is essential to ensure a balance-energy-mix, where every other type of energy will have a role to play to avoid dependence on only one solution for the future. Therefore, in contrast to the dwindling fossil fuels, it can be generally speculated that the future for biorefining is bright. It was concluded that with vast knowledge on the suitable heterogeneous catalysts and proper optimization of process parameters (temperatures, pressure, and reactant species); some of the biorefining processes will result into a significant increase in industrial fuels and bio-based drop-in chemicals leading towards commercialization.
\end{abstract}

Keywords: biorefining, pyrolysis, transesterification, depolymerization, valorization, deactivation, biomass, hydrothermal liquefaction, lignin and catalysts

\section{INTRODUCTION}

Biorefining encompasses the selection, conversion and/or processing of biomass into value-added products, specifically, fuels and chemicals. Just like the refinery process converts oils to light and heavy hydrocarbon fuels and further into useful chemicals, the biorefinery utilize several known chemical processes into the valorization of biomass to chemicals. Elliot (2004) suggests that most chemicals from petroleum, used in food additives, clothing fibers, plastics in cars and paints, can as well be obtained from the biorefinery process. In recent years, aromatics, for example, gained its major boost in demand, as it is a major feedstock in the chemical industry (Reif et al., 2020). To ensure meeting this high Benzene,
Toluene and Xylene (BTX) demand, the depolymerization of lignin-fraction from wood, by the Diels-Alder reaction pathway has been utilized (Maneffa et al., 2016; Reif et al., 2020). Pyrolysis oil, for example, has shown to contain about 400 different compounds, where the feed composition determine its chemical properties (Yaman, 2004). The monolignols obtained from lignin depolymerization contain mainly alcohols. These monomers (which basically includes $\mathrm{G}$ - coniferyl alcohol, H - p-coumaryl alcohol and S - sinapyl alcohol) (Crocker and Santillan-Jimenez, 2020), transforms into chemicals of better-quality such as vanillin, vanillic acid and syringaldehyde, which have high market value (Song et al., 2018). The demand for biofuels relies on its transmissibility, which is the ease with which the fuel has transported to the higher its demand. The production and demand for biogas 
घermany $\quad$ United Kingdom $\quad$ France $\quad$ Italy $\quad$ Other Countries

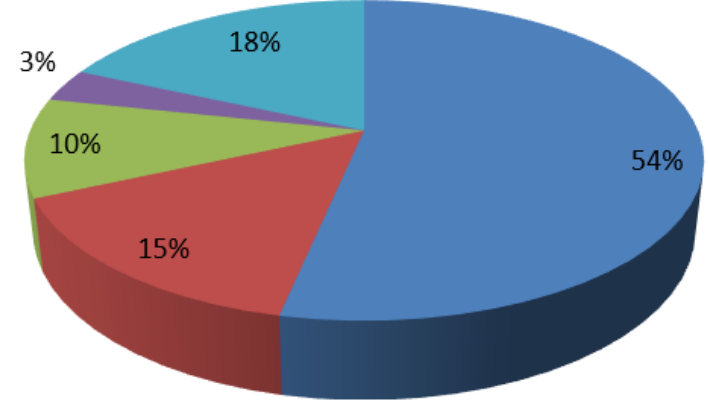

Figure 1. Units of biogas produced in Europe (Capodaglio and Bolognesi, 2019)

(which contain chiefly methane) are huge in Europe, and its use varies from cooking to heating (Capodaglio and Bolognesi, 2019) (Figure 1).

Ma et al. (2012) estimate that about an approximate value of 0.73 billion agricultural deposits produced per annum can correspond to 12000 trillion KJ of energy. The processing of first-generation biofuels was ineffective in Asia, as it couldn't fulfill the energy requirements for its population. Also, the outsized population in Asia (particularly China), was enough drawback for first-generation biofuels feedstock to thrive, as it competes greatly with human food. Within the searches of the authors of this work, there hasn't been a review that tackles specifically, thermo-chemical biorefinery processes and emphasizes more on their most perceived procedural drawbacks coupled with techno-economic analysis.

Therefore, the objective is to recognize emerging technologies, clarify problems, elucidate the techno-economic analysis of thermochemical processes, underline comprehensive comparisons between related thermochemical processes, evaluate research progress as it examines the most common biorefinery processes and finally, provides a feasible solution to the prevailing disadvantages encountered. This review would add to the continued drive towards energy and environmental sustainability.

\section{OVERVIEW OF SOME SELECTED PROCESSES FOR BIOMASS UPGRADING}

The earliest (or first-generation) forms of biomass for fuels were plants, which competes greatly with food for humans. There has been a drift from the first to the second and third generation, which doesn't compete with human food, has come to stay. Biomass required for processing, can either be lingo-cellulosic biomass like corn cobs, corn stover, straw, husks and sugarcane bagasse. Other forms include algae, fats and oils, are reliable and easily sourced alternatives to declining fossil fuels (Morales et al., 2020). The significant drift from the petroleum-based products to bio-based products is as a result of improved biorefining techniques. Over the years, the massive advancements from slow to fast pyrolysis, to the addition of multiple catalysts to help result in stable products, to lignin depolymerization. The US Department of Energy envisaged that within 2020-2050, biomass should make up about $10 \%$ - 50\% (respectively) of the basic chemical building blocks of bio-based products (Elliott, 2004).
Irrespective of the low yields of bio-products from biorefining, researchers continue to devise new chemical techniques and approach, to improve on the yields and product quality. The scope of this paper covers both thermal and catalytic selected biorefinery process like Biomass gasification, Slow to fast pyrolytic processes, Transesterification of lipids, lignin depolymerization and Catalytic fast pyrolysis. In the generation of pyrolysis oil by pyrolysis, there are investigations that the liquid can either be used directly in the application, of subjected to further upgrading or processing. The side biochar is not left behind; it is also applied in the industry as solid fuels or specifically in purification (Onay and Kockar, 2008). The Hydrodeoxygenation (HDO) process is applied to convert biooil to fuel. The process is still not efficient, due to the unstable bio-oil produced. The need to produce thermally stable bio-oil lead to the introduction of catalysts in the pyrolytic process (Crocker and Santillan-Jimenez, 2020), making the pyrolysis either ex-situ or in-situ. Recently, researcher's attention has moved into the valorization of lignin and it was found to be useful (Song et al., 2018). Lignin which is structural glue in the plant secondary cell wall is formed from radical polymerization of monolignols. The bonding pattern is formed by the radical linking of the monolignols by radical polymerization. Therefore, to valorize valuable products like vanillic acid and syringaldehyde, the bonding pattern has to be depolymerized. When vegetable oil is transesterified, a blend of glycerin and fatty acids alkyl esters is formed. This is only possible in the presence of a catalyst (alkali or acid), when an alkanol reacts with a triglyceride. According to Demirbas (2003), this process of transesterification is commonly used. The base-catalyzed process executes speedily compared to the acid catalyzed process, making it the most preferred. The pyrolysis oil is a dark brown organic liquid, composed of several compounds such as oligomers, alkanols, alkanals, phenols and carboxylic acids, etc. Rahman et al. (2018) suggests the drawbacks for the use of the promising bio-oil, which involves thermal and chemical instability, high viscosity, high moisture and corrosiveness. Compared to the heating value of fossil fuels, which take a range from 40 to 45 $\mathrm{MJ} / \mathrm{Kg}$, the pyrolysis oil is relatively small. The higher heating value (HHV) for bio-oil ranges from $16.79-19 \mathrm{MJ} / \mathrm{Kg}$ which is as a result of moisture and oxygenated components present, thereby making the pyrolysis oil not fit for use directly as transportation fuels (Taarning et al., 2011).

The spectrum of selected thermo-chemical processes from lipids and lignocellulosic biomass, adapted from Ma et al. 


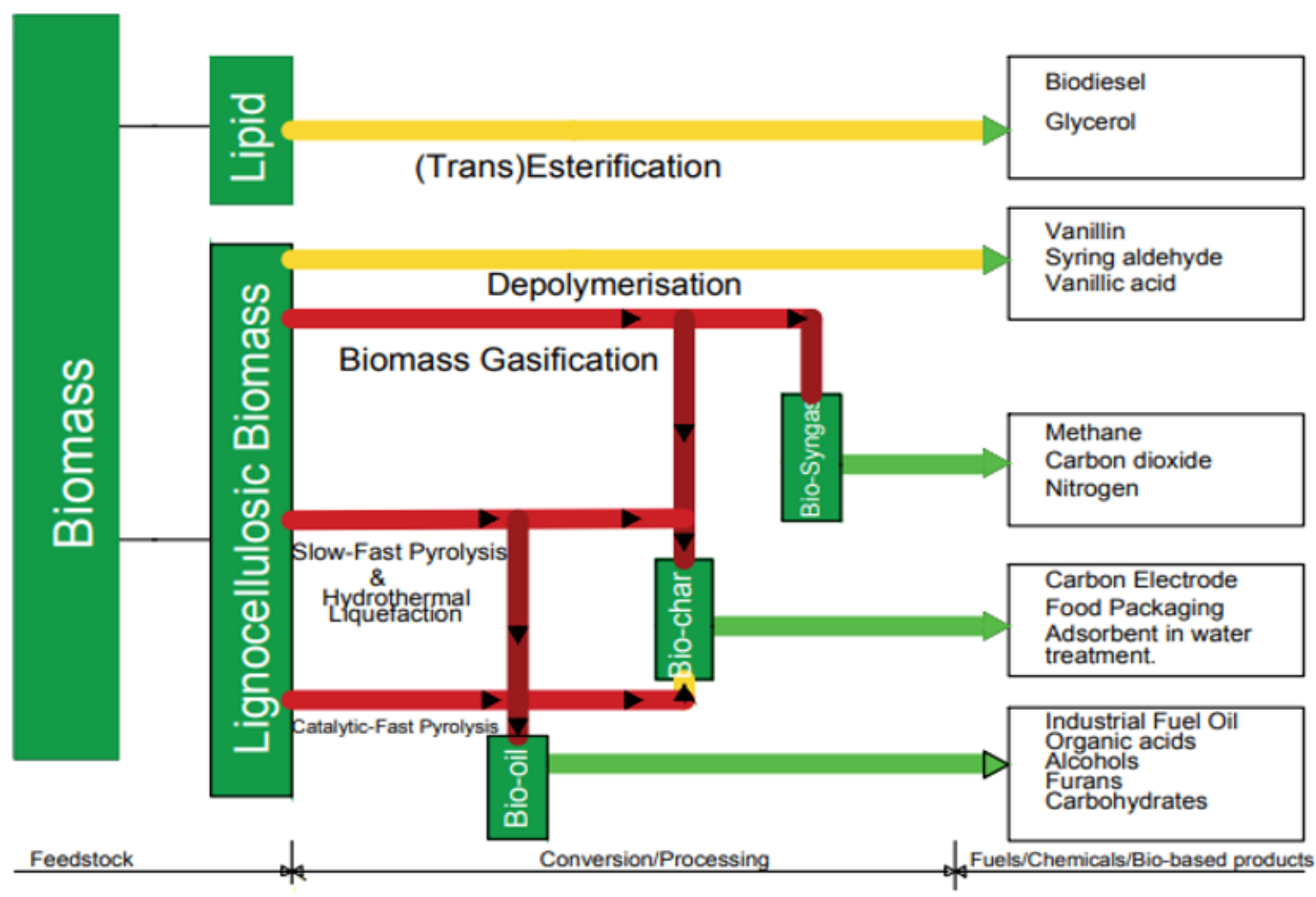

Figure 2. The spectrum of thermo-chemical processes

(2012) shown in Figure 2, involves the process pathways of how fuels and chemicals are made from biogenic feedstock. The flowsheet properly extends from the biomass or bio-path process (Green), through either a catalytic (Yellow) or thermal (Red) process to ensure the proper conversion of biomass.

It is paramount to differentiate between the different pathways involved and chemicals obtained from biomass utilization. These chemicals are more efficient, of high product quality, and more expensive compared to their petroleumbased counterparts. These quality products from biogenic sources can be classified into Drop-ins, Smart Drop-ins and Dedicated Chemicals. The process tracks taken for the transformation are called pathways. Hence, the conventional pathway follows the track taken to convert natural gas, petroleum and ash or coal to valuable products. Figure 3 shows a schematic description of biological- and petroleumbased pathways to chemicals.

Bio-based drop-in chemicals are structurally similar to chemicals based on petroleum (Gerardy et al., 2020). Drop-ins use the biomass as a raw material and at an early stage join the traditional pathway. Compared to petroleum-based alternatives, they are manufactured in greater quantities and therefore costlier (Carus et al., 2017). Ethene, polyethene, polypropene and Polyethene terephthalate (PET) are examples of drop-ins. Smart drop-ins' chemicals are a particular subdivision of drop-in chemicals; the approach involves initially using the biomass-related method until at a late stage joining the traditional pathway. Generally, smart drop-ins are lower in quantity. Ethanoic acid, propenoic acid, adipic acid, butadiene and Isoprene are examples, etc. An entirely different direction from the traditional pathway follows dedicated bio-based chemicals. They may not have similar equivalents based on fossils. They are used to manufacture high quality products that can't be manufactured by conventional chemical process (Carus et al., 2017). Compared to the others, the dedicated chemicals are more powerful as they use not only carbon but also the whole biomass, which includes carbon, nitrogen, hydrogen and oxygen. Therefore, the use of the complete biomass represents a high efficiency of biomass use (BUE) (Iffland et al., 2015). The comparison of various chemical groups from the use of biomass is shown in Table 1.

\section{TRENDING SELECTED PROCESSES FOR THERMO-CHEMICAL BIOREFINING AND THEIR CHEMICALS}

\section{Biomass Gasification}

Biomass gasification encompasses the incomplete oxidation of biomass, to a mix of combustible gases. The biomass ranges from agricultural residue, wood to coal, while the mixtures of gases (called syngas) are methane, carbon dioxide and hydrogen. Other wastes could be biochar, coal tar and ashes etc. According to the World Bioenergy Association (WBA), gasification originated in the 1800 s as a process used to produce town gas, used in cooking and lightening. Hence, it is not a new technology (World Bioenergy Association, 2015). Gasification lost its attention, but regained it in the World War II, as a result of the shortage in liquid fuels available then (Kirkels and Verbong, 2011). Gasification process is safe, effective and highly organized method of biorefining with a wide variety of applicability offered by feedstock. The feedstock applications primarily include heating, electricity, 


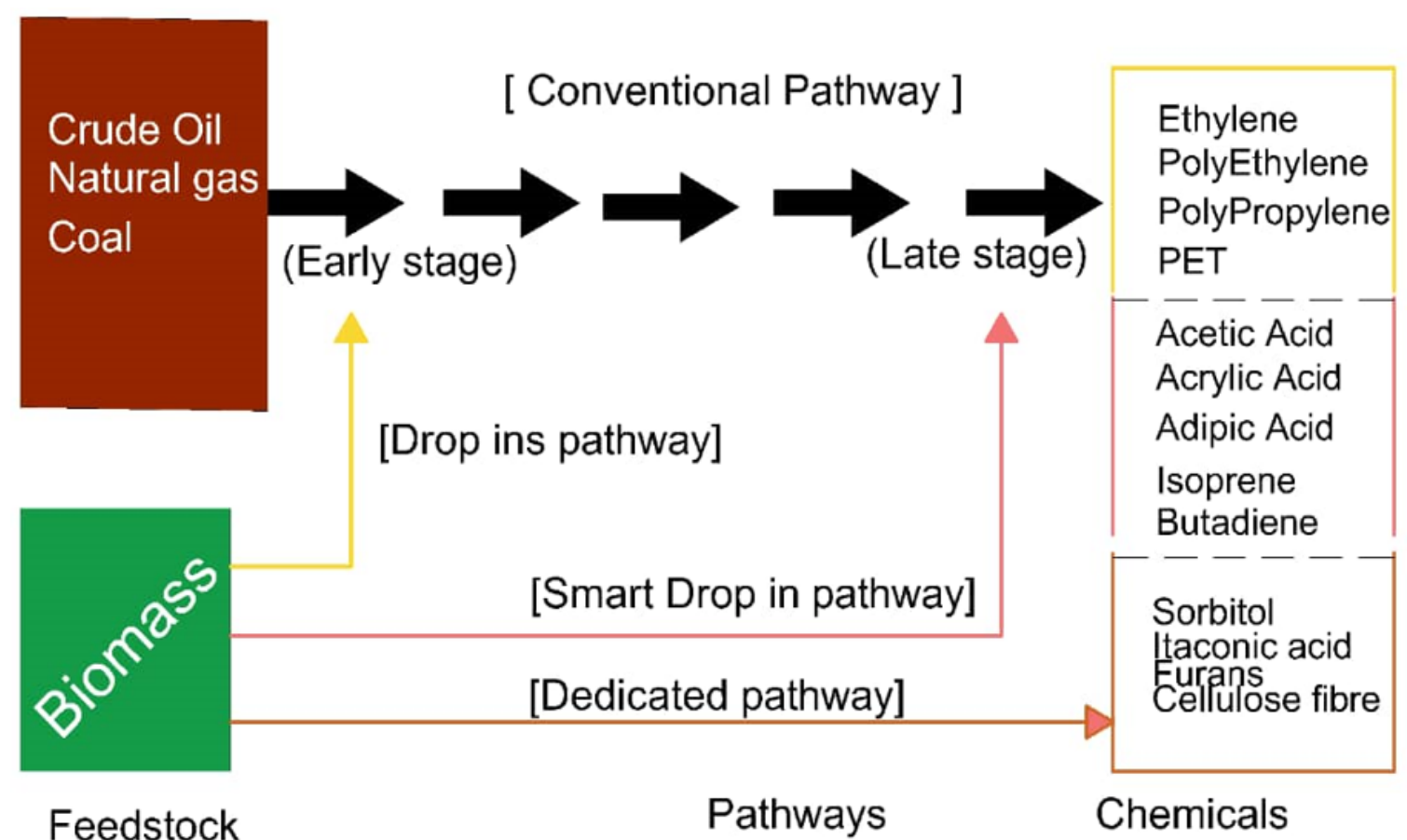

Figure 3. Schematic descriptions of bio- and petroleum-based pathways to chemicals

Table 1. Assessments of different chemical class from biomass utilization

\begin{tabular}{ccccccc}
\hline Chemicals & $\begin{array}{c}\text { Biomass } \\
\text { Utilization } \\
\text { Efficiency (BUE) }\end{array}$ & $\begin{array}{c}\text { Petroleum } \\
\text { Equivalence }\end{array}$ & Product Quantity & Product Quality & $\begin{array}{c}\text { Pathway } \\
\text { Efficiency }\end{array}$ & $\begin{array}{c}\text { Cost (compared to } \\
\text { petroleum-based } \\
\text { products) }\end{array}$ \\
\hline Drop-ins & $<100 \%$ & Yes & Large & Better & Efficient & Expensive \\
\hline Smart Drop-ins & $<100 \%$ & Yes & Small & More Better & More Efficient & Expensive \\
\hline Dedicated & $100 \%$ & No & Medium/Large & Novel & Most Efficient & Expensive \\
\hline
\end{tabular}

chemicals and fuels for transport. Wood, mainly dominant in Canada, Finland, Sweden and the USA, is the most used feedstock for biomass gasification as the USA becomes the leading region (Kirkels and Verbong, 2011). The goal was to seek for a potential substitute for natural gas or transportation fuels. De Lasa (2011) proposes that biomass gasification process generates very minute levels of particles, together with a small amount of NOx and SOx when measured up with fossil fuels. Although the unwanted particulate poses a challenge to the biomass gasification process, it can as well be utilized effectively. The tar is thermally transformed when the gasifier operates at elevated temperatures; even at additional $1000^{\circ} \mathrm{C}$ it's difficult to completely remove tars (MoralesDelarosa and Campos-Martin, 2014). As opposed to the use of increase temperature to reduce the tar formation, the increased temperature can also make the process highly not economically feasible (Asadullah et al., 2001).

The introduction of catalysts can be approached in two groups, the first group, which is the chief catalysts, is positioned in the gasifier, while inside the reactor, the other group of catalyst is placed. The major challenge in the use of varied catalysts in catalyst biorefining technique, such as catalytic fast pyrolysis, is the presence of coke, which is capable of deactivating the catalysts. Using a nickel catalyst for example in a gasifier (De Lasa et al., 2011) works perfectly on time. When in the gasifier for long, it deactivates due to the deposition of carbon and prolonged sintering (Bulushev and Ross, 2011; De Lasa et al., 2011). The combined use of nickel catalyst with either dolomite or olivine seemed promising, after about 60hours of operations (Bulushev and Ross, 2011). This for sure has been effective for pilot-scale production using the biomass gasification process (Pfeifer et al., 2004). Biomass required for gasification is usually of great amount, to get a significant large energy application. Several technologies have been advanced over the years to manage biomass feedstock usage. A set-up, in form of a co-gasification technique with coal or co-combustion with natural gas in an associated cycle is an alternative approach to properly manage the use of the biomass feedstock (Kirkels and Verbong, 2011). Due to the enormous energy required in a gasifier, the risk and cost of setting up the process seem quite outrageous (Maithel, 2009). Figure 4 shows a plot of several fuels (solid, liquid and gaseous fuel) against their respective calorific values. From the plot, their average calorific value is high for gases and relatively low for solids, and an intermediate value for the liquid form.

Most deposits, bagasses and waste are basically used for production of power and heat generation in the industries (specifically, sugar industry) in East Africa. The heating rate for most biomass fuels is 10-16 MJ/kg (Parasnis, 2010). Residues and organic wastes have shown to be the widely used biomass basis, but arguably, the economic value of bioenergy crops has increased remarkably. 


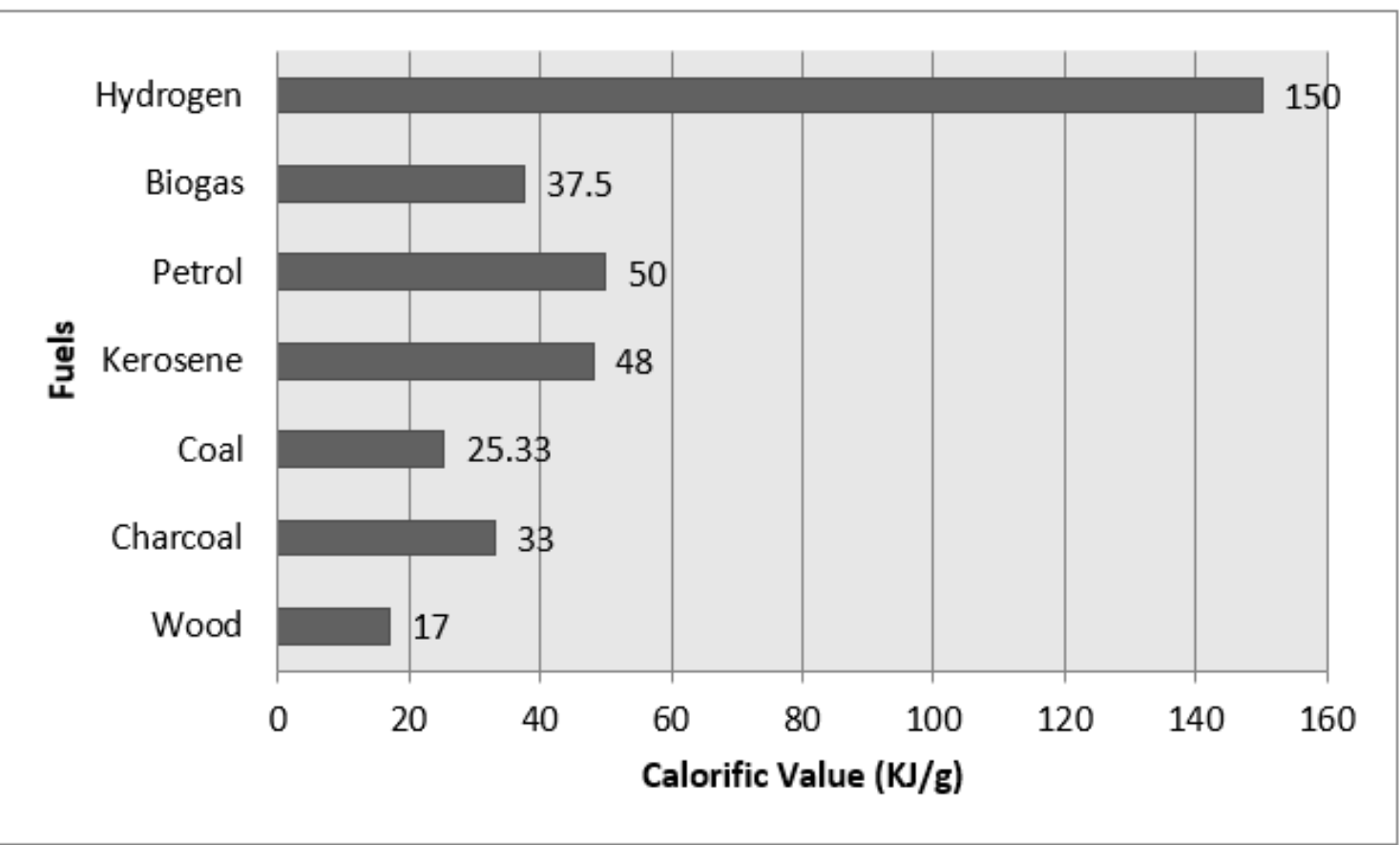

Figure 4. Sample substance heating value

Table 2. Wt \% of bio-products generated from fast pyrolysis using different biomass

\begin{tabular}{cccccccc}
\hline Biomass & Pyrolysis Type & $\begin{array}{c}\text { Temp Range } \\
{\left[{ }^{\circ} \mathbf{C}\right]}\end{array}$ & $\begin{array}{c}\text { Heating Rate } \\
{\left[{ }^{\circ} \mathbf{C} / \mathbf{s}\right]}\end{array}$ & $\begin{array}{c}\text { Bio-char } \\
{[\mathbf{W t} \text { \%] }}\end{array}$ & $\begin{array}{c}\text { Bio-oil } \\
{[\mathbf{W t} \text { \%] }}\end{array}$ & $\begin{array}{c}\text { Gas } \\
{[\mathbf{W t} \text { \%] }}\end{array}$ & Ref \\
\hline Sewage Sludge & Fast & 500 & 0.17 & - & 45.2 & 7.2 & Cao et al. (2010) \\
\hline Grape Bagasse & Fast & $350-600$ & 0.83 & 33.0 & 23.81 & 30.01 & Demiral and Emine (2010) \\
\hline Wood waste & Fast & 500 & 0.17 & - & 39.7 & 22.2 & Cao et al. (2010) \\
\hline Corncob & Fast & 700 & 85 & 20.2 & 54.2 & 21.3 & Huiyan et al. (2008) \\
\hline Pig compost & Fast & 500 & 0.17 & - & 44.4 & 8.4 & Cao et al. (2010) \\
\hline
\end{tabular}

\section{Slow/Fast Pyrolysis}

The thermal breakdown of lignocellulosic biomass composed mainly of the long polymeric chain of cellulose, hemicellulose and lignin is carried out under certain operating conditions in an oxygen-deficient environment to yield different products. The products which consist of condensable liquids (bio-oils, tar and water), residual solids (bio-char) and gases (like $\mathrm{CO}_{2}, \mathrm{H}_{2}, \mathrm{CO}$ and hydrocarbons like $\mathrm{CH}_{4}, \mathrm{C}_{2} \mathrm{H}_{4}, \mathrm{C}_{2} \mathrm{H}_{6}$ ) depend on the method of pyrolysis, the characteristics of the biomass and the operating conditions giving rise to different pyrolytic processes like the slow and fast pyrolysis. Slow pyrolysis also known as conventional pyrolysis or carbonization is one of the oldest types of pyrolysis. This method dates as far back as human history until the early 1900s where coal, acetic acid, methanol and ethanol where obtained from the slow pyrolysis of wood (Generation, 2019). It is characterized by a slower heating rate usually $<1^{\circ} \mathrm{C} / \mathrm{S}$, a lower pyrolysis temperature ranging from $300^{\circ} \mathrm{C}$ to $600^{\circ} \mathrm{C}$ and a longer residence time. Slow pyrolysis maximizes the production of biochar and gases which can be condensed into a liquid. In other to obtain sufficient bio-char, biomass with large particle size (5 - $50 \mathrm{~mm}$ ), little ash content, high lignin content and fixed carbon should be used (Yaning et al., 2019). Bio-char is valued for its carbon storage ability and has also proven to be useful in soil amendment due to its hygroscopic and porous nature. Bio-oil obtained from pyrolysis are good sources of renewable fuels (they are $\mathrm{CO}_{2}$ neutral) and are also good feedstock for the production of chemicals such as biolime (Czernik and Bridgwater, 2004). In contrast, fast pyrolysis is ideal for the production of gaseous and liquid products. It is most commonly used for research and real-life application and is characterized by a high rate of heating, the gas residence time of a few seconds and an instant cooling of the vapour produced (Pfitzer et al., 2016). Careful selection of the feedstock must be done to maximize the pyrolysis oil yield. The moisture content should be around $10 \%$ or lower and the biomass should be reduced to fine particles usually $<1 \mathrm{~mm}$ to increase the rate of disintegration leading to a greater yield (up to $70 \%$ ) of bio-oil. The ideal feedstock for fast pyrolysis is one with a substantial amount of hemicellulose, cellulose substrate and extractives as they easily decompose to yield condensable vapours and gases. Biomass like wheat straw, corncob and barley straw is good bio-oil feedstock whereas, walnut shell, nutshell and hazelnut shell are good feedstock for bio-char production because of their rich lignin content (Chowdhury et al., 2017). Tables 2 and 3 shows the percentage distribution of the products obtained from fast and slow pyrolysis respectively using different biomass.

\section{Catalytic Fast Pyrolysis}

Pyrolysis which involves the non-oxidative heating of organic materials is a process involved in the conversion of lignocellulosic biomass to a dark liquid called bio-oil (Crocker and Santillan-Jimenez, 2020). Conventional operating 
Table 3. Wt \% of bio-products generated from slow pyrolysis using different biomass

\begin{tabular}{cccccccc}
\hline Biomass & Pyrolysis Type & $\begin{array}{c}\text { Temp Range } \\
{\left[{ }^{\circ} \mathbf{C}\right]}\end{array}$ & $\begin{array}{c}\text { Heating Rate } \\
{\left[{ }^{\circ} \mathbf{C} / \mathbf{s}\right]}\end{array}$ & $\begin{array}{c}\text { Bio-char } \\
{[\text { Wt \%] }}\end{array}$ & $\begin{array}{c}\text { Bio-oil } \\
{[\text { Wt \%] }}\end{array}$ & $\begin{array}{c}\text { Gas } \\
{[\mathbf{W t} \text { \%] }}\end{array}$ & Ref \\
\hline Thistle & Slow & 550 & 0.67 & 54.1 & 24.7 & 18.1 & Gercel (2011) \\
\hline Bamboo biomass & Slow & 300 & 0.17 & 80 & 4 & 16 & Laidy et al. (2014) \\
\hline Live Oak & Slow & 500 & 0.5 & $22-28$ & $44-54$ (tar) $18-30$ & Safdari et al. (2019) \\
\hline Spark berry & Slow & 500 & $0.83-0.5$ & 26.1 & 50.2 (tar) & 29.1 & Amini et al. (2019) \\
\hline Yaupon & Slow & 500 & $0.83-0.5$ & 27.3 & 48.9 (tar) & 20.5 & Amini et al. (2019) \\
\hline
\end{tabular}

conditions for pyrolysis are usually a temperature of $500^{\circ} \mathrm{C}$ and pyrolysis pressure of $1 \mathrm{~atm}$. The fast pyrolysis seems advantageous, because of the high yield of bio-oil and its corresponding bio-char. The bio-oil is usually thermally unstable, which limits its commercial use. Zhang et al. (Zhang et al., 2007) Suggests that bio-oil possesses a higher viscosity, poor volatility, lower heating value due to $35-40 \%$ oxygen content. The presence of oxygen poses a great challenge to biomass-derived products, obtained from lignocellulosic biomass. To address this challenge, this excess oxygenated compounds needs to be removed. The viable approach to the removal of oxygen from biomass-derived molecule is deoxygenation, which could be in form of deocarbonylation/decarboxylation (deCOx) and hydrodeoxygenation (HDO). The hydrodeoxygenation (HDO) of lipids (specifically, vegetable oils), basically composed of triglycerides to alkanes, oleic and linoleic acids with $\mathrm{C}=\mathrm{C}$ bonds is required to generate quality biofuels (Serrano-Ruiz and Dumesic, 2011). Although, HDO seems to be environmentally friendly, because it removes $\mathrm{CO}_{2}$ and $\mathrm{H}_{2} \mathrm{O}$ compared to deCOx reaction. The HDO process joins the $\mathrm{C}$ $\mathrm{O} / \mathrm{C}=\mathrm{O}$ bond thus maintaining the carbon chain length (Lin et al., 2018). This is only made possible, by the introduction of metallic catalyst. Transition metal carbides (TMCs) have emerged as promising HDO catalysts. Robinson et al. (2016) investigated bifunctional catalysts specifically for the HDO reaction of bio-oil and its derivatives from biomass, with a target on the reactivity and how it is influenced by catalyst structures.

Ma et al. (2012) carefully outlined several catalytic chemical processes used in the enhancement of bio-oil to energy and chemicals. Bio-oil physico-chemical properties are highly unstable, which hinders its application. Hence there is a need for upgrading (Bunch et al., 2018). The Catalytic fast pyrolysis (CFP) involves catalytic processing of pyrolysis vapors either in situ (where pyrolysis and catalysis take place in same reactor vessel) or ex-situ (where the pyrolysis and catalysis take place in a separate reactor) (Crocker and Santillan-Jimenez, 2020). Each methodological approach comes with its drawbacks. The catalytic fast pyrolysis over zeolites (HZMS-5), through acid-catalyzed dehydration, at the active sites of the catalyst (zeolite) cellulose produces anhydro-sugar (Carlson et al., 2009). Hence, the anhydrosugar is further converted into lighter olefins of $\mathrm{C}_{2}-\mathrm{C}_{6}$ forms, via oligomerization, decarboxylation and decarbonylation, and ultimately, the lighter olefins come together to produce aromatics, via aromatization of olefins (Rahman et al., 2018). Furans go through a succession of catalytic decarbonylation and oligomerization reactions and then generate aromatics (monocyclic and polycyclic) together with olefins through hydrocarbon group mechanism. Zeolite, which is a framework of mainly silica $\left(\mathrm{SiO}_{2}\right)$ and alumina $\left(\mathrm{Al}_{2} \mathrm{O}_{3}\right)$, is the most applicable catalyst for CFP (Crocker and Santillan-Jimenez, 2020).

Dong et al. (2012) propose that, due to complicated structure of phenyl propane monomers, called guaiacyl, syringyl, and p-hydroxylphenyl, lignin has the least susceptibility during catalytic pyrolysis. Raman et al. (2018) have clearly outlined several factors which may be essential to enhance the value of bio-oil yields. The presence of oxygenating species, increased viscosity and low energy density etc. are some of these restrictions. The amount of biooil generated, is heavily dependent on the catalyst properties i.e., pore size, crystallite size and chemical structure, as well as operating conditions, plays a very important role. Moreover, the yield and quality of bio-products of catalytic pyrolysis rely on the composition of biomass, the mode of reaction and the operating condition (ranging from residence time, heating rate, temperature, the particle dimensions or size of biomass and form of catalysts, etc.). In the context of zeolites, bio-oil deoxygenation is a function of the Silica/Alumina ( $\mathrm{Si} / \mathrm{Al}$ ) ratio and needs modifying the mesoporous zeolites with a decreasing $\mathrm{Si} / \mathrm{Al}$ ratio for higher bio-oil and chemical yields. As a competent technique for generating high-quality bio-oil and chemicals from biomass substrates, Catalytic co-pyrolysis is used. Feedstock rich in hydrogen content is used in copyrolysis as a co-feeder. It is also possible to minimize oxygenating components and mutagenic polyaromatic hydrocarbons in bio-oil produced, by catalytic co-pyrolysis of the biomass feedstock with a hydrogen-loaded co-feeder (Crocker and Santillan-Jimenez, 2020; Rahman et al., 2018).

\section{(Trans)esterification}

A traditional method to manufacture biodiesel is transesterification, which can also be called alcoholysis. It is known to be the most efficient way to turn big triglyceride molecules into smaller, straight-chain fatty acid ester molecules. According to Zhang et al. (2003), the molecular weight will decrease by a factor of eight to one-third that of oil and viscosity, as well as increase its volatility. In vegetable oil transesterification, in the presence of a strong acid or alkali catalyst (acid-catalyzed or alkali-catalyzed processes), triglycerides react with alcohol, creating a mixture of methyl ester (FAME) and glycerol fatty acids. The transesterification is a stable response and basically, the conversion occurs by mixing the reactants uniformly (Demirbas, 2003). On the other hand, excess alkanol is used to increase alkyl esters yields and to allow proper separation from the glycerol formed (Anusi et al., 2018a, 2018b), and biodiesel yield increases with reaction time and is best at an elevated temperature of $60^{\circ} \mathrm{C}$ when palm kernel oil (PKO) has been transesterified. Transesterification 
Table 4. Oil content for biodiesel feedstock (Baskar and Aiswarya, 2016)

\begin{tabular}{|c|c|c|}
\hline Type of Oil & Feedstock & Oil content \% \\
\hline \multirow{4}{*}{ Edible } & Soybean & $15-20$ \\
\hline & Sunflower & $25-35$ \\
\hline & Coconut & $63-65$ \\
\hline & Palm & $30-60$ \\
\hline \multirow{3}{*}{ Non-edible } & Jatropha seed & $35-40$ \\
\hline & Neem oil & $20-30$ \\
\hline & Castor & 53 \\
\hline \multirow{3}{*}{ Other sources } & Rubber seed & $40-50$ \\
\hline & Sea mango & 54 \\
\hline & Cottonseed & $18-25$ \\
\hline
\end{tabular}

is therefore dependent on hydrodynamics, the power of the catalyst and the quality of the feedstock.

\section{Triglyceride (TG) +3 R' OH $\rightarrow$ Glycerol (GL) + 3R'COOR3}

Biodiesel's merits outweigh its demerits, and thus, making it a good alternative to fuels from petroleum and have led to its use, especially in areas that are environmentally sensitive and where feedstock is readily available. Biodiesel high flash point of $150^{\circ} \mathrm{C}$ makes it safer to transport, less volatile and also safer to treat than diesel oil. Biodiesel offers lubricating properties capable of reducing engine abrasion and prolonging engine life (Von Wedel, 1999). It is understood that transesterification reactions are acid-catalyzed, alkalicatalyzed, or catalyzed by enzymes. As a consequence of its effectiveness, acid and alkali-catalyzed transesterification reactions have long been used. As for the enzyme-catalyzed reaction, an increased reaction time is required compared to the other two (Watanabe et al., 2001). The draw back to the commercialization of biodiesel is due to its high cost of production, as the feedstock pretreatment plant alone, is enough to affect the return on investment of the entire process (Zhang et al., 2003). This shows that the biodiesel industry has not completely seen the light. Biodiesel typically costs over US\$ $0.5 / \mathrm{L}$, compared to US\$ $0.35 / \mathrm{L}$ for diesel from petroleum source (Lott, 2002). But still, there is a major downside to petroleum diesel. For several years, the use of these petroleum diesel sources of energy has resulted in an increase in global warming (Ogunwole, 2012).

Gashaw and Teshita (2014) suggests that transesterification is a conventional method introduced to minimize the viscosity during biodiesel synthesis, done in the presence of an alkanol. However, several factors such as reaction temperature and time, the molar ratio of alcohol, and catalyst concentration, affect the biodiesel production by transesterification. The production cost of biodiesel occupies about $75 \%$, which make up feedstock and catalysts (Capodaglio and Bolognesi, 2019). Biodiesel is a blend of fatty acid methyl esters obtained from both edible and non-edible oil, as shown in Table 4 (Baskar and Aiswarya, 2016).

Glycerol is the other product that comes from the transesterification process. Compared to the purified clear form, glycerol obtained from transesterification is typically very crude, dark and viscous. The method for purifying crude glycerol requires isopropyl alcohol (IPA) neutralization, glycerol concentration, decolorization and glycerol concentration, which ultimately results in refined glycerol (Muniru et al., 2016). Glycerol can be used for the manufacture of lubricants, cosmetics, paper, plastics, paints, etc. as a feedstock. Its application varies considerably, as it is essential for both fine and heavy chemical manufacturing. A distilled or processed glycerol is commonly advertised on the market as 99.5-99.7\% pure (Saifuddin et al., 2014). Glycerol in its pure form can be used in the food and pharmaceutical industries after transesterification with a high yield of crude glycerol, which can further be oxidized, reduced, halogenated, etherified and esterified to achieve different product chemicals (Javani et al., 2012).

\section{Lignocellulosic Biomass Depolymerization}

Lignin is known to act as structural glue between the cellulose and the hemicellulose of secondary cell wall of plants. Lignocellulosic biomass is compound blend of natural polymers - these materials contain cellulose within the range of $35-50 \%$, hemicelluloses occupying $25-30 \%$, and lignin $15-$ $30 \%$ - firmly merged by both physical and chemical interactions (Rubin, 2008). Technical lignin is generated from chemical or laboratory process such as pulping and can be used in the generation of fuels. These lignins could be any of lignosulfonate, Kraft and organosolv lignin. The complication of the lignocellulosic biomass makes it hard for chemical transformations. In sugar, for example, cellulose hydrolysis needs a severe condition to occur, conditions such as the use of concentrated acids at high temperatures, but the $\beta$ glycosidic linkages of the sugar molecules contained in cellulose or lignocelluloses are powerfully sheltered by the firm packing of cellulose chains in micro fibers, resulting into difficulty in hydrolysis (Morales-Delarosa and CamposMartin, 2014). Monolignols obtained from lignin depolymerization contain mainly alcohols. These monomers (G - coniferyl alcohol, S - sinapyl alcohol and H - p-coumaryl alcohol), combine by radical polymerization to form a bonding pattern called $\beta$-Aryl ether $(\beta-0-4)$. In lignin depolymerization, the aim is to depolymerized (or delignify) the bonding pattern, $\beta$-Aryl ether ( $\beta-\mathrm{O}-4)$, which is formed by radical linking of lignin monomers. The depolymerization of $\beta$-Aryl ether ( $\beta-0-4)$ is due to the presence of benzylic alcohol, to produce aromatic monomers (Crocker and SantillanJimenez, 2020). The $\beta$-Aryl ether ( $\beta-\mathrm{O}-4)$ is abundant in lignin and takes up to about $60 \%$ structural linkages, followed by the $\beta-5$ and $\beta-\beta$ as well as other minor units (Song et al., 2018). It is reported that the depolymerization process needs a rigorous reaction condition like high temperature and pressure, extended reaction time and involve the use of corrosive chemicals (Forsythe et al., 2013).

Lignin has a convoluted make-up with low reactivity, according to Chio et al. (2019), which restricts its use, hence 
Table 5. Selected examples of Base catalyzed depolymerized lignin at different conditions (Rößiger et al., 2018)

\begin{tabular}{|c|c|c|c|c|}
\hline \multirow{2}{*}{ Feedstock } & \multirow{2}{*}{ Base Catalysts } & \multicolumn{2}{|c|}{ Reaction Parameters } & \multirow{2}{*}{$\begin{array}{l}\text { Products and } \\
\text { Composition }\end{array}$} \\
\hline & & Reaction Conditions & Reaction Systems & \\
\hline $\begin{array}{l}\text { Organosolv lignin beech Wood } \\
\text { and lignoboost craft lignin }\end{array}$ & $\begin{array}{l}5 \% \text { Lignin in } 1-5 \text { wt \% } \\
\mathrm{NaOH} \text { - Solution }\end{array}$ & $\begin{array}{c}250 \text { bar; } 5,10,15 \mathrm{~min} \text { at } \\
250-340^{\circ} \mathrm{C}\end{array}$ & $\begin{array}{l}\text { Plug-flow reactor, } \\
\text { Continuous mode }\end{array}$ & $\begin{array}{c}\text { Oil content produced } \leqslant 23 \\
\text { wt\% }\end{array}$ \\
\hline Organosolv lignin & $\begin{array}{l}2.5-10 \text { wt\%, } 2.5 \text { wt\% } \\
\text { NaOH-solution }\end{array}$ & $\begin{array}{l}250-315 \text { bar, retention time } \\
2-15 \text { min at } 240-340^{\circ} \mathrm{C}\end{array}$ & $\begin{array}{l}\text { Continuous mode of a } \\
\text { Plug-flow reactor }\end{array}$ & $\begin{array}{l}\sim 22 \mathrm{wt} \% \text { oil and } \sim 15 \mathrm{wt} \% \\
\text { oligomers }\end{array}$ \\
\hline Steam explosion hemp lignin & $\begin{array}{l}5 \text { wt \% lignin in } \mathrm{NaOH} \\
\text { solution }\end{array}$ & $90-130$ bar at $300-330^{\circ} \mathrm{C}$ & $\begin{array}{c}\text { Batch wise mode of } \\
\text { operation }\end{array}$ & $\begin{array}{l}\text { About } 11 \text { wt \% monomer } \\
\text { species }\end{array}$ \\
\hline Softwood indulin lignin & $\begin{array}{c}10 \mathrm{wt} \% \text { lignin in a } \\
\text { solution of } 5 \mathrm{wt} \% \mathrm{NaOH}\end{array}$ & $\begin{array}{c}\text { LHSV } 1.4-4 \text { h-1 at } 270- \\
315^{\circ} \mathrm{C}\end{array}$ & $\begin{array}{c}\text { Plug flow reactor at } \\
\text { Continuous mode of } \\
\text { operation }\end{array}$ & $\begin{array}{l}\text { solid product } \leqslant 70 \mathrm{wt} \% \text { and } \\
\text { some organic compounds }\end{array}$ \\
\hline Residue from corn stover & $\begin{array}{c}10 \text { wt \% lignin, } 2-4 \text { wt \% } \\
\text { NaOH solution }\end{array}$ & $270-300^{\circ} \mathrm{C}$ & $\begin{array}{l}\text { Batch wise mode of } \\
\text { operation }\end{array}$ & Soluble fractions $\leqslant 78 \mathrm{wt} \%$ \\
\hline
\end{tabular}

the reason it's burned off as energy. However, the reactivity of the structural lignin is much lower than that of the lignin fragment, due to the reactive site being obstructed by the complex lignin formation. The sources of chemicals from lignin are very impressive, as the aliphatic and aromatic hydroxyl groups are major components and active sites in technical lignin. In chemical manufacturing, scientific lignin is extracted from industrial by-products that can be used as well as feedstock. Thus, about $30 \%$ of petroleum-based polyols have been substituted by technical lignin for the production of polyurethane (Cateto et al., 2008). Several catalysts ranging from acids, bases, metallic catalysts and ionic liquids are used for lignin depolymerization. Acid-catalyzed depolymerization is widely researched but has its related challenges (Chio et al., 2019).

A lot of metallic catalysts also have been investigated which includes noble metals $(\mathrm{Ru}, \mathrm{Pd}, \mathrm{Pt}$, and Ti except $\mathrm{Ni}$ ), cheap metals ( $\mathrm{Cu}, \mathrm{Mo}, \mathrm{Al}, \mathrm{Fe}, \mathrm{Zn})$, their combination and alloy (Zhai et al., 2017). Chio et al. (2019) in their work displayed the efficacy of $\mathrm{Ru}$ in specifically converting corn stalk lignin to4ethylphenol and 4-ethylguaiacol with the yields of 3.10wt\% and $1.37 \mathrm{wt} \%$ at $275^{\circ} \mathrm{C}, 90 \mathrm{~min}, 2 \mathrm{MPa}$. Song et al. (2018) employed $\mathrm{Au}$ nanoparticles (NPs) and Li-Al layered double hydroxide (LDH) as support, and it showed an outstanding result in oxidation of the benzylic group. The applications of metallic catalysts in lignin depolymerization can the limited by catalyst deactivation and low conversion rate (around 50$60 \%)$. Due to the deactivation of the catalysts, it is not costeffective, especially when compared to acid or base which can almost completely convert lignin to other valuable chemicals in the course of the reaction (Chio et al., 2019). The most prevalent method for lignin depolymerization is the oxidative depolymerization. It involves breaking the $\beta$-Aryl ether $(\beta-O$ 4) linkage pattern. Hydrogen peroxide and other oxidants are used in oxidation, which shows how cheap the process can be. The over-oxidation could increase the complexity of the lignin structure, which cause a difficulty of separating the products. Notwithstanding, biocatalyst require comparatively moderate reaction conditions when it compares to others. The biocatalysts involved specifically for biomass treatments and lignin depolymerization have been understudied for decades (Jennings et al., 2017). It is envisaged that the use of strong bases, like $\mathrm{KOH}, \mathrm{NaOH}$ can transform and produce more depolymerized products rather than the weak bases, like $\mathrm{Ca}(\mathrm{OH})_{2}$ and $\mathrm{LiOH}$ (Evans et al., 1996). Selected examples of
Base catalyzed depolymerized lignin at different conditions are shown in Table 5.

\section{Hydrothermal Liquefaction}

An emerging thermo-chemical process is the Hydrothermal Liquefaction (HTL), it basically involves the conversion of wet biomass, or organic materials in any form (including algae) into biocrude, biochar and gases, such as $\mathrm{H}_{2}$, $\mathrm{CO}_{2}$ and $\mathrm{CH}_{4}$ (Castello et al., 2018). This process takes place at about $250-450^{\circ} \mathrm{C}$ and at a pressure of $100-350 \mathrm{bar}$, with their respective catalysts as shown in Table 6. Several configurations have been set up for the HTL process, which can either take effect as a batch or continuous process. The relatively simplistic approach of the continuous configuration makes it heavily reported by literatures compared to the batch techniques (Toor et al., 2011; Zhu et al., 2015a, 2015b). In the batch approach, an autoclave is used as the batch reactor. The wet feedstock is fed into the autoclave, set at required temperature and further heated to a required time in the presence of a catalyst, after which the products are collected. Comparing the pyrolysis process with the HTL, Elliot et al. (1993) proposed that the HTL process is superior and differ in both biomass preparation and reactor configurations as shown in Table 7. According to Castello et al. (2018), there are several drawbacks with the batch technique, and this includes difficulty in coupling temperature and pressure, thermal transition, different contacting pattern and ultimately, HTL requires a systematic energy optimization which only be achieved in a continuous configuration.

\section{ADVANCEMENTS, TECHNO-ECONOMIC ANALYSIS AND CHALLENGES ON BIOREFINING}

The circular economy was invented as a feasible alternative to the present model of economic growth that promoted the system of "produce, consume, dispose." A remarkable approach was considered to be the implementation of biorefining as a strategy to achieve the circular economy principle as it would serve as a solution to the disadvantages surrounding waste generation by anthropological practices. Life cycle assessment (LCA) is a scientific methodology used to systemically analyze the environmental impact created after the useful life of a product, service or process (Ubando et al., 
Table 6. HTL biomass selection and operating conditions

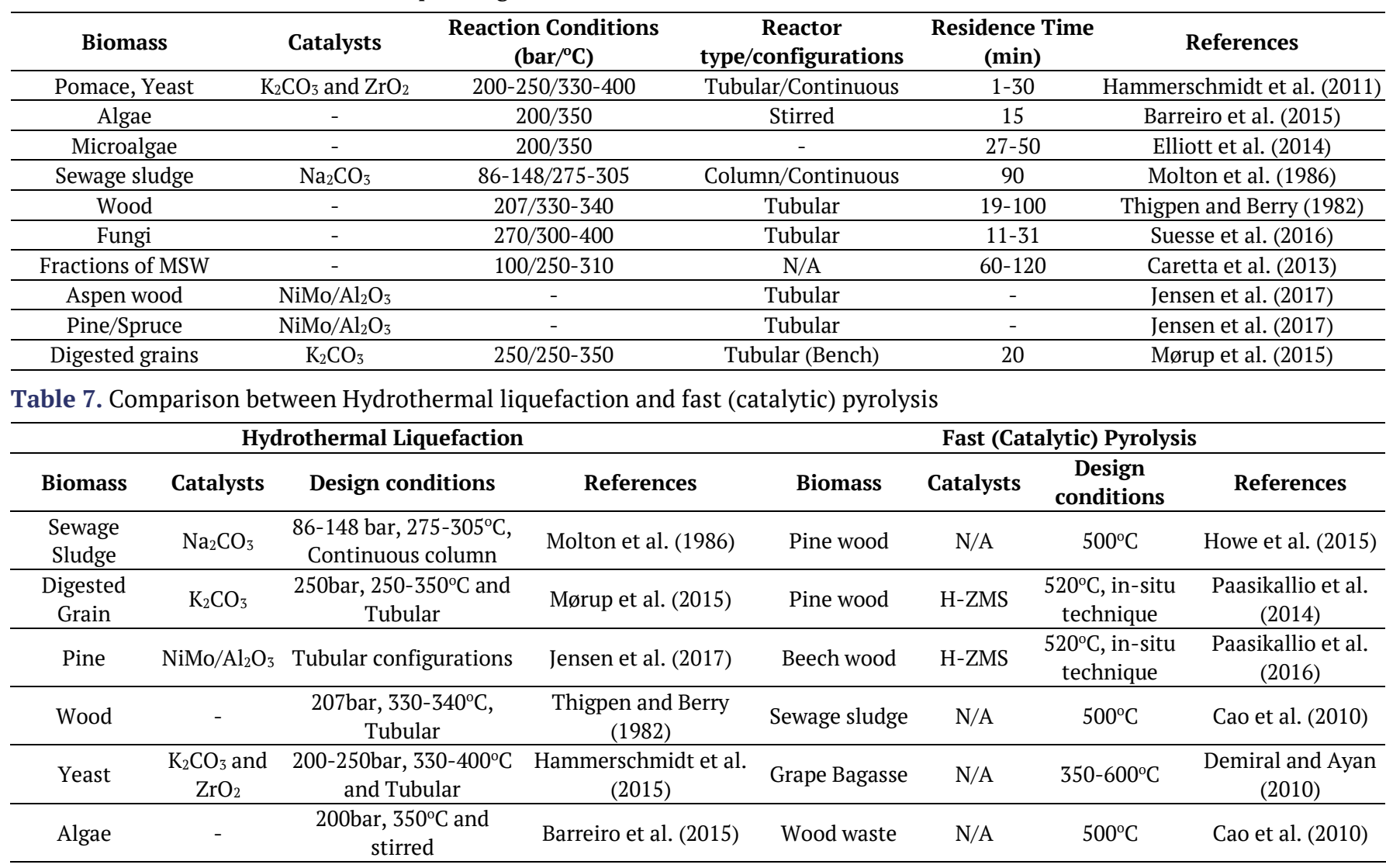

2019). This impact check begins at the point of extraction of raw materials through to processing/manufacturing, transportation and distribution, usage and disposal. Lifecycle assessment is very important in today's pursuit for sustainability as it critically evaluates and compares products, processes or services thereby helping us choose those with the least impact on the environment. For life-cycle environmental impacts, feedstocks have quite an immeasurable effects on biofuels produced. These impacts are made obvious amongst agricultural feedstocks, as lignocellulosic biomasses, from the point of extraction to the biorefinery plants. Lange (2007) suggests that the cost of both technology and feedstock used affects the conversion of biomass to biofuels. Important factors need to be considered in the setting up of a biorefinery; even more important is the techno-economic analysis, which is evaluated by several parameters such as production cost and income. It is pertinent to note that the price of some parameters greatly depends on the production technology, just as the cost variation for feedstock is also related to the purity of the product. Mandegari et al. (2017) suggested that these parameters are connected to several indicators such as total manufacturing cost, net present value, payback period, fixed capital cost, and break-even price and after-tax rate of return. Pedersen et al. (2017) evaluated the economic feasibility of gasoline equivalents production through hydrothermal liquefaction of aspen wood, by means of three different case scenarios. According to their research, sensitivity analysis predicts that the biocrude yield from the HTL process is the most responsive parameter for the fuel production cost; other important economic parameters are feedstock price, thermal energy, and these parameters helps in the performance of the HTL process.
The key issues to be addressed by the assessments of renewable resources for sustainable production of energy, oils, chemicals and polymers are of growing demands, gradual reduction of fossil fuels, an increase in the price of crude oil and environmental degradation (Rostrup-Nielsen, 2005). With the International Energy Agency's estimated biofuel production of approximately 25\% in 2024 (IEA, 2019), bioenergy would certainly make a major contribution to the global energy mix, and biorefining will be an exceptional tool in achieving sustainable growth. Biorefining was first described as a process in the 1990s (Maity, 2014) and has since developed, although it is still evolving. The International Energy Agency (IEA) describes it as the sustainable processing of biomass into a continuum of bio-based and bio-energy products that are marketable (IEA Bioenergy - Task 42, 2019). The goal of biorefinery, as suggested by Cherubini (2010), is to increase the use of biomass and to reduce the waste and pollution connected with its transformation into bioenergy and bio-based goods.

Since initiation, biorefining processes have continued to advance. Biomass feedstock selection, policies, technologies and refining processes are constantly being investigated to utilize the intrinsic potentials available therein. Some of the biggest and most recent advancements in the biorefining process include:

i. Sustainable government policies: According to Herman et al. (2011), government policies have always been important for promoting sustainable socio-economic development. In their current guiding principles affecting the market permeation of biomaterials stated that biofuels for transportation is supported regionally 
by the EU biofuels directive and nationally by the US Energy Policy Act (2005) (Herman et al., 2011). Also, the German Renewable Energy (GRE) Law is another policy strengthening electricity and biofuel generation and distribution from biomass (REN21, 2009). It also accounts for about $46 \%$ of the fuel used in municipal heating in 2013 (Ericsson and Werner, 2016).

ii. The introduction of big data analytics in biorefineries in line with the new industrial era (industry 4.0): As the world population continues to increase, amounting to about 7 billion, there is need for a large volume of products (chemicals, energy, fuels, etc.) to meet demand sustainably. In the fast world, big data analytics coupled with machine learning is improving the overall biorefining process. Biorefineries are generally integrated with several units requiring constant monitoring of several process parameters by plant personnel. The commencement of platforms like Enterprise Manufacturing Intelligence (EMI) streamline the process of contextualizing process data which is shown for easy visualization for knowledgedriven decisions, giving birth to smart biorefineries that would be effective in the nearest future (Chiang et al., 2017).

Challenges of biorefining are:

i. There are varied biomass feedstocks available for biorefining processes which can be grouped as; agricultural residues, algae, forestry residue, waste streams and non-reusable carbon sources. This variety comes with huge disproportions that make it difficult to create a system that can accommodate all feedstocks in a single class. There are four biorefinery systems, which are green refineries, lingo-cellulosic feedstock biorefinery, whole-crop biorefinery and two-platform concept (Roland and Jean-Michel, 2013). This has continued to impose challenges because while the conversion of corn/sugarcane to bioethanol and waste to biogas have been well-studied and established other biomass processing routes featuring the second and third-generation biofuels using agricultural, forest, municipal waste and algae are still ongoing research and development. And as such, they are commercially non-competitive (Ralph et al., 2010; Roland, A. L. and Jean-Michel, 2013).

ii. Technological advancement is another factor with enormous impact on biorefining. The knowledge gap with the second and third-generation biofuels is greatly wide. According to Ralph et al. (2010), improved research techniques and technology would help in the understanding of feedstock including the production, transportation, storage and refining processes (including biochemical, chemical and thermochemical). Lignocellulosic biomass is the next most plentiful polymer; yet, it is being under-utilized despite. Hence, lignin is generally burned to provide power/heat as opposed to its economical use in the production of chemicals, fuels, and other products (Yamakawa et al., 2018). This is attributed to the difficult nature of lignin which inhibits cellulose and hemicellulose hydrolysis (Akhar et al., 2016).
Interestingly, pre-treatment or preparation processes constitute about $20 \%$ of the conversion cost (Mafe et al., 2015) and until cost-effective and environmentally soothing pre-treatment technologies are established. Hence, lignin-based products will continue to be economically infeasible (Baruah et al., 2018).

iii. Accessibility of biogenic feedstock all year round for commercial-scale production and the danger connected with land use.

iv. Land use, afforestation and water: The issue of land for arable purpose, afforestation and water remains one of the biggest challenges of biofuel because till date majority of biofuels produced worldwide are derived from first and second generation sources. According to a report carried out by Organisation for Economic Cooperation and Development (OECD) in 2019, 25\% of sugarcane and $14 \%$ of global maize would be used in the production of bioethanol by 2028 . This simply means that vast land mass would be used to cultivate sugarcane and maize for industrial purpose which could lead to food scarcity or undue increase in food price. Several thousands of forests are been destroyed to be able to provide feedstock (lignocellulosic biomass) for the production of biofuel.

\section{CONCLUSION AND OUTLOOK}

In the last decade, biofuels such as bioethanol, biodiesel and bio-gasoline have become an issue of global importance as man tries to fight environmental degradation and global climate change. According to World Energy Council (2016), bioethanol and biodiesel are the two common types of biofuel and are expected to increase globally to 140 billion litres and 46 billion litres respectively by 2029. Various models of biofuels have been proposed from first generation down to the fourth generation, some operational others still developing. Canada is still considered to be a major biofuel producer in the world producing over 250 million liters of biofuel annually (Mabee, n.d.). One would only wonder how other continents like Asia, Africa and few other developing countries are working towards energy sustainability.

For biorefining process to be a success, it involves proper understanding of the feedstock selection (biomass), processes (chemistry and technology) involved and finally the bio-based products (fuels and chemicals) to be achieved. The forthcoming biorefinery will have a huge influence on society as fossil-based resources become inadequate and more costly, it is even projected that biorefinery would overwhelm the petroleum refinery. Therefore, to properly maintain the balance of demand to energy, the use of biomass to complement petroleum, is the only known alternative to meet society demands in supplying new hydrocarbon-based chemical products. The beauty of biorefining is that it incorporates not just the prolificacy and involvement of the fine and heavy chemical industries, but it also places agriculture (afforestation) at the forefront of the economy. The need for afforestation and non-food crop cultivation would eventually pick up drastically. Even though the technological impediments for biomass gasification are much, it cannot be 
denied that the products are useful, as attention for both gasification and pyrolysis should concentrate mainly on product enhancements. The lignin component which is the least utilized of the biomass fractions is often viewed as a fuel to drive the processing systems, but it is also a possible basis of aromatic chemical products. Other thermochemical processes like gasification and pyrolysis should concentrate on the scaling up and integration with current plants (Umenweke, Great, 2020). The pretreatment process of the lignocellulosic biomass has to be maintained properly in a cost-effective way, for commercialization. Furthermore, if attention should shift towards the second-generation biofuels (lignocellulosic biomass), composed of rice husk, corn stovers, energy grasses etc. due to its non-competitiveness as food crops or materials, it would make the conversion of biomass to energy a very promising venture to embark. As biofuel continues to advance, there is no doubt that this new drive towards clean energy will open a world of opportunities some of which includes:

- The need for R \& D: There is need to bridge the gap between the realities of today and the possibilities of tomorrow. For example, even though it is possible to mass culture algae for oil production, the cost of production is still reasonably high due to the advanced technology involved (Benemann, 2008). It is possible for cost effective measures to be implemented and technologies deployed to allow for competitiveness in this method of biofuel generation.

- Waste Water: More opportunities would be presented with respect to water treatment and purification as almost all biofuel production is water dependent. This is obviously an aspect of biofuel production researchers need to look into, to ensure the biomass valorization process is highly environmental friendly in almost every aspect.

\section{ABBREVIATIONS}

Mtoe- Million Tonnes of Oil Equivalent, BTX- Benzene Toluene Xylene, HDO- Hydrodeoxygenation, WBA - World Bioenergy Association, CFP- Catalytic Fast Pyrolysis, HZSM-5$\mathrm{H}$-form of Zeolite Silicony Mobile -5, PKO- Palm Kernel Oil, IPA- Isopropyl Alcohol, NPs- Nanoparticles, LDH-Layered Double Hydroxide, LHSV-Liquid hourly space velocity. SOxSulphur oxides, NOx-Nitrogen oxides, EMI-Enterprise Manufacture Intelligence, GRE-German Renewable Energy, LCA-Life Cycle Assessments, HTL-Hydrothermal Liquefaction.

Author contributions: All co-authors have involved in all stages of this study while preparing the final version. They all agree with the results and conclusions.

Funding: No external funding is received for this article.

Declaration of interest: The authors declare that they have no competing interests.

Ethics approval and consent to participate: Not applicable.

Availability of data and materials: All data generated or analyzed during this study are available for sharing when appropriate request is directed to corresponding author.

Acknowledgement: The team acknowledges Ugochukwu Sylva for his assistance with the flowchart drawings.

\section{REFERENCES}

Akhar, N., Gupta, K., Goyal, D. and Goyal, A. (2016). Recent advances in pre-treatment technologies for efficient hydrolysis of lignocellulosic biomass. Environmental Progress and Sustainable Energy, 35(2), 489-511. https://doi.org/10.1002/ep.12257

Amini, E., Safdari, M.-S., Deyoung, J. T., Weise, D. R. and Fletcher, T. H. (2019). Characterization of pyrolysis products from slow pyrolysis of live and dead vegetation native to the southern United States. Fuel, 2019(235), 14751491. https://doi.org/10.1016/j.fuel.2018.08.112

Anusi, M. O., Umenweke, G. C., Nkuzinna, O. and Igboko, N. (2018a). Kinetics of alkali catalyzed transesterification reaction of palm kernel oil and physicochemical characterization of the biodiesel product. American Journal of Engineering Research (AJER), 7(2), 73-82. https://www.researchgate.net/publication/324797946

Anusi, M. O., Umenweke, G. C., Oyoh, K. B., Nkuzinna, O. and Njoku, C. N. (2018b). Characterization of non-edible oil from waste plant materials for biodiesel production. American Journal of Engineering Research (AJER), 7(4), 3236. https://www.researchgate.net/publication/324798033

Asadullah, M., Fujimoto, K. and Tomishige, K. (2001). Catalytic performance of $\mathrm{Rh} / \mathrm{CeO} 2$ in the gasification of cellulose to synthesis gas at low temperature. Industrial \& Engineering Chemistry Research, 40, 5894-5900. https://doi.org/10.1021/ie010160z

Barreiro, D. L., Gómez, B. R., Hornung, U., Kruse, A. and Prins, W. (2015). Hydrothermal Liquefaction of Microalgae in a Continuous Stirred-Tank Reactor. Energy Fuels, 29, 64226432. https://doi.org/10.1021/acs.energyfuels.5b02099

Baruah, J., Nath, B. K., Sharma, R., Kumar, S., Deka, R. C., Barauh, D. C. and Kalita, E. (2018). Recent trends in the pre-treatment of lignocellulosic biomass for value-added products. Frontiers in Energy Research, 6, 141. https://doi.org/10.3389/fenrg.2018.00141

Baskar, G. and Aiswarya, R. (2016). Trends in catalytic production of biodiesel from various feedstocks. Renewable and Sustainable Energy Reviews, 57, 496-504. https://doi.org/10.1016/j.rser.2015.12.101

Benemann, J. R. (2008). Opportunities and Challenges in algae biofuel production, future energy events. Available at: www.futureenergyevents.com/algae/attend/

Bulushev, D. A. and Ross, J. R. H. (2011). Catalysis for conversion of biomass to fuels via pyrolysis and gasification: A review. Catalysis Today, 171(1), 1-13. https://doi.org/10.1016/j.cattod.2011.02.005

Bunch, A. Y., Wang, X. Q. and Ozkan, U. S. (2008). Adsorption characteristics of reduced Mo and Ni-Mo catalysts in the Hydrodeoxygenation of benzofuran. Applied Catalysis A: General, 346(1-2), 96-103. https://doi.org/10.1016/ j.apcata.2008.05.007 
Cao, J. P., Xiao, X.-B., Zhang, S.-Y., Zhao, X.-Y., Sato, K., Ogawa, Y., Wei, X.-Y. and Takarada, T. (2010). Preparation and Characteristics of Bio-oils from internally circulating fluidized-bed pyrolysis of municipal, livestock and wood waste. Bioresource Technology, 102(2), 2009-2015. https://doi.org/10.1016/j.biortech.2010.09.057

Cao, J.-P., Xiao, X.-B., Zhang, S.-Y., Zhao, X.-Y., Sato, K., Ogawa, Y., Wei, X.-Y. and Takarada, T. (2010). Preparation and Characteristics of Bio-oils from internally circulating fluidized-bed pyrolysis of municipal, livestock and wood waste. Elsevier. https://doi.org/10.1016/j.biortech.2010.09. 057

Capodaglio, A. G. and Bolognesi, S. (2019). Ecofuel feedstocks and their prospects. In Advances in Eco-Fuels for a Sustainable Environment (pp. 15-51). https://doi.org/ 10.1016/B978-0-08-102728-8.00002-4

Caretta, A., Riccò, M., Bosetti, A., Burattini, M., Carnelli, L., Miglio, R. and Volpato, C. B. (2013). Waste to fuelConversion of waste into energy. In Proceedings of the 9th European Congress of Chemical Engineering, The Hague, The Netherlands.

Carlson, T. R., Tompsett, G. A., Conner, W. C. and Huber, G. W. (2009). Aromatic production from catalytic fast pyrolysis of biomass-derived feedstocks. Topics in Catalysis, 52(2009), 241. https://doi.org/10.1007/s11244-008-9160-6

Carus, M., Dammer, L., Puente, Á., Raschka, A. and Arendt, O. (2017). Bio-based drop-in, smart drop-in and dedicated chemicals. Road to Bio. Nova Institut 2017. Available at: https://www.roadtobio.eu/uploads/news/2017_October/Ro adToBio_Drop-in_paper.pdf

Castello, D., Pedersen, T. H. and Rosendahl, L. A. (2018). Continuous Hydrothermal Liquefaction of Biomass: A Critical Review. Energies, 11, 3165. https://doi.org/10.3390/ en11113165

Cateto, C. A., Barreiro, M. F. and Rodrigues, A. E. (2008). Monitoring of lignin-based polyurethane synthesis by FTIR-ATR. Industrial Crops and Production, 27(2), 168-174. https://doi.org/10.1016/j.indcrop.2007.07.018

Cherubini, F. (2010). The biorefinery concept: Using biomass instead of oil for producing energy and chemicals. Energy Conversion and Management, 51(7), 1412-1421. https://doi.org/10.1016/j.enconman.2010.01.015

Chiang, L., Lu, B. and Castillo, I. (2017). Big Data Analytics in Chemical Engineering. Annual Review of Chemical and Biomolecular Engineering, 8, 63-85. https://doi.org/10.1146/ annurev-chembioeng-060816-101555

Chio, C., Sain, M. and Qin, W. (2019). Lignin utilization: A review of lignin depolymerization from various aspects. Renewable and Sustainable Energy Reviews, 107, 232-249. https://doi.org/10.1016/j.rser.2019.03.008

Chowdhury, Z. Z., Kaushik, P., Wageeh, A. Y., Suresh, S., Syed, T. S., Ganiyu, A. A., Emy, M., Rahman, F. F. and Rafie, B. J. (2017). Pyrolysis: A sustainable way to generate energy from waste. Intechopen. https://doi.org/10.5772/intechopen. 69036

Crocker, M. and Santillan-Jimenez, E. (2020). Chemical catalyst for biomass upgrading. Wiley-VCH. https://doi.org/ 10.1002/9783527814794
Czernik, S. and Bridgwater, A. V. (2004). Overview of applications of Biomass fast Pyrolysis Oil. Energy and Fuels, 18(2), 590-598. https://doi.org/10.1021/ef034067u

De Lasa, H., Salaices, E., Mazumder, J. and Lucky, R. (2011). Catalytic steam gasifi cation of biomass: catalysts, thermodynamics and kinetics. Chemical Reviews, 111, 5404-5433. https://doi.org/10.1021/cr200024w

Demiral, I. and Ayan, E. A. (2010). Pyrolysis of grape bagasse: Effect of pyrolysis conditions on the product yields and characterization of the liquid product. Bioresource Technology, 102(4), 3946-3951. https://doi.org/10.1016/ j.biortech.2010.11.077

Demiral, I. and Emine, A. A. (2010). Pyrolysis of grape bagasse: Effect of pyrolysis conditions on the product yields and characterization of the liquid product. Bioresource Technology, 102(4), 3946-3951. https://doi.org/10.1016/ j.biortech.2010.11.077

Demirbas, A. (2003). Biodiesel fuels from vegetable oils via catalytic and non-catalytic supercritical alcohol transesterifications and other methods: A survey. Energy Conversion and Management, 44(13), 2093-2109. https://doi.org/10.1016/S0196-8904(02)00234-0

Dong, C. Q., Zhang, Z. F., Lu, Q. and Yang, Y. P. (2012). Characteristics and mechanism study of analytical fast pyrolysis of poplar wood. Energy Conversion and Management, 57(2012), 49-59. https://doi.org/10.1016/ j.enconman.2011.12.012

Elliot, D. C., Sealock, L. J., Phelps, M. R. and Neuenschwander, G. G. (1993). Development of a catalytic system for gasification of wet biomass. Presented at First Biomass Conference of the Americas, Burlington, Vermont. https://doi.org/10.2172/10120451

Elliott, D. C. (2004). Biomass, Chemicals from. In Encyclopedia of Energy (vol. 1). https://doi.org/10.1016/B0-12-176480$\mathrm{X} / 00358-2$

Elliott, D. C., Hart, T. R., Neuenschwander, G. G., Rotness, L. J., Roesijadi, G., Zacher, A. H. and Magnuson, J. K. (2014). Hydrothermal processing of macroalgal feedstocks in continuous-flow reactors. ACS Sustainable Chemistry \& Engineering, 2(2), 207-215. https://doi.org/10.1021/ sc400251p

Ericsson, K. and Werner, S. (2016). The introduction and expansion of biomass use in Swedish district heating systems. Biomass and Bioenergy, 94, 57-65. https://doi.org/10.1016/j.biombioe.2016.08.011

Evans, L., Littlewolf, A., Lopez, M. and Miller, J. (1996). Batch microreactor studies of base catalyzed liginin depolymerization in alcohol solvents. Albuquerque, NM, and Livermore, CA: Sandia National Laboratories.

Forsythe, W. G., Garrett, M. D., Hardacre, C., Nieuwenhuyzen, M. and Sheldrake, G. N. (2013). An efficient and flexible synthesis of model lignin oligomers. Green Chemistry, 15(11), 3031. https://doi.org/10.1039/c3gc41110a

Gashaw, A. and Teshita, A. (2014). Production of biodiesel from waste cooking oil and factors affecting its formation: A review. International Journal of Renewable and Sustainable Energy, 3(5), 92-98. https://doi.org/10.11648/j.ijrse. 20140305.12 
Generation. (2019). Pyrolysis: A Basket of Biomass Potential. ESI Africa, 2, 86-87. Available at: https://www.esiafrica.com/industry-sectors/generation/pyrolysis-abasket-of-biomass-potential/

Gerardy, R., Debecker, D. P., Estager, J., Luis, P. and Manbaliu, J.-C. M. (2020). Continuous Flow Upgrading of selected $\mathrm{C}_{2}-$ $\mathrm{C}_{6}$ platform chemicals derived from biomass. Chemical Reviews, 120(15), 7219-7347. https://doi.org/10.1021/ acs.chemrev.9b00846

Gercel, H. F. (2011). Bio Production from Onopordumacanthium acanthium L. by Slow Pyrolysis. Journal of Analytical and Applied Pyrolysis, 92(1), 233-238. https://doi.org/10.1016/ j.jaap.2011.06.002

Hammerschmidt, A., Boukis, N., Galla, U., Dinjus, E. and Hitzmann, B. (2011). Conversion of yeast by hydrothermal treatment under reducing conditions. Fuel, 90, 3424-3432.

Hammerschmidt, A., Boukis, N., Galla, U., Zevaco, T., Dinjus, E. and Hitzmann, B. (2015). Influence of the heating rate and the potassium concentration of the feed solution on the hydrothermal liquefaction of used yeast and apple pomace under reducing conditions. Biomass Conversion Biorefinery, 5, 125-139. https://doi.org/10.1007/s13399014-0148-0

Hermann, B., Carus, M., Patel, M. and Blok, K. (2011). Policy, regulation and certification: Current policies affecting the market penetration of biomaterials. Biofuels, Bioproducts \& Biorefining, 5, 708-719. https://doi.org/10.1002/bbb.327

Howe, D., Westover, T., Carpenter, D., Santosa, D., Emerson, R., Deutch, S., Starace, A., Kutnyakov, I. and Lukins, C. (2015). Field-to-Fuel Performance Testing of Lignocellulosic Feedstocks: An Integrated Study of the Fast Pyrolysis-Hydrotreating Pathway. Energy Fuels, 29, 31883197. https://doi.org/10.1021/acs.energyfuels.5b00304

Huiyan, Z., Rui, X., Huang, H. and Gang, X. (2008). Comparison of non-catalytic and catalytic fast pyrolysis of corncob in a fluidized bed reactor. Bioresource Technology, 100(3), 14281434. https://doi.org/10.1061/j.biortech.2008.08.031

IEA (2019). Renewables 2019: Analysis and forecast to 2024. International Energy Agency, France 5. Available at: www.iea.org

IEA Bioenergy - Task 42. (2019). Biorefining in a circular economy. Available at: http://task42.ieabioenergy.com/

Iffland, K., et al. (2015). Definition, Calculation and Comparison of the "Biomass Utilization Efficiencies (BUE)" of Various Bio-based Chemicals, Polymers and Fuels. Hürth 2015-11. Available at: https://news.biobased.eu/nova-paper-8-published/

Javani, A., Hasheminejad, M., Tahvildari, K. and Tabatabaei, M. (2012). High quality potassium phosphate production through step-by-step glycerol purification: A strategy to economize biodiesel production. Bioresource Technology, 104, 788-790. https://doi.org/10.1016/j.biortech.2011.09. 134
Jennings, J. A., Parkin, S., Munson, E., Delaney, S. P., Calahan, J. L., Isaacs, M., Hong, K and Crocker, M. (2017). Regioselective Baeyer-Villiger oxidation of lignin model compounds with tin beta zeolite catalyst and hydrogen peroxide. RSC Advances, 7, 25987-25997. https://doi.org/ 10.1039/C7RA03830E

Jensen, C. U., Guerrero, J. K. R., Karatzos, S., Olofsson, G. and Iversen, S. B. (2017). HydrofactionTM of forestry residues to drop-in renewable transportation fuels. In L. Rosendahl (Ed.), Direct Thermochemical Liquefaction for Energy Applications (pp. 319-345). Sawston, UK: Woodhead Publishing-Elsevier. https://doi.org/10.1016/B978-0-08101029-7.00009-6

Jensen, C. U., Rosendahl, L. A. and Olofsson, G. (2017). Impact of nitrogenous alkaline agent on continuous HTL of lignocellulosic biomass and biocrude upgrading. Fuel Processing Technology, 159, 376-385. https://doi.org/ 10.1016/j.fuproc.2016.12.022

Kirkels, A. F. and Verbong, G. P. J. (2011). Biomass gasification: Still promising? A 30-year global overview. Renewable and Sustainable Reviews, 15(2011), 471-481. https://doi.org/ 10.1016/j.rser.2010.09.046

Laidy, E. H., Arai, A. P. and Antonio, L. B. (2014). Slow pyrolysis of bamboo biomass: Analysis of biochar properties. Chemical Engineering Transactions, 2014(37), 115-120. https://doi.org/10.3303/CET1437020

Lange, J. P. (2007). Lignocellulose conversion: an introduction to chemistry, process and economics. Biofuels, Bioproducts, and Biorefining, 1(1), 39-48. https://doi.org/10.1002/bbb.7

Lin, Z., Chen, R., Qu, Z. and Chen, J. G. (2018). Hydrodeoxygenation of biomass-derived oxygenates over metal carbides: from model surfaces to powder catalysts. Green Chemistry, 20(12). https://doi.org/10.1039/ C8GC00239H

Lott, M. (2002). QSS Group Inc., 4500 Forbes Boulevard, Suite 200, Lanham, MD 20706.

Ma, L., Wang, T., Liu, Q., Zhang, X., Ma, W. and Zhang, Q. (2012). A review of thermal-chemical conversion of lignocellulosic biomass in China. Biotechnology Advances 30(4), 859-873. https://doi.org/10.1016/j.biotechadv.2012. 01.016

Mabee, W. E. (n.d.). Policy Options to Support Biofuel Production. In Biofuels (Part of the Advances in Biochemical Engineering / Biotechnology, pp. 329-357). https://doi.org/10.1007/10_2007_059

Mafe, O. A., Davies, S. M., Hancock, J. and Du, C. (2015). Development of an estimated model for the evaluation of the energy requirement of dilute acid pretreatments of biomass. Biomass and Bioenergy, 72, 28-38. https://doi.org/10.1016/j.biombioe.2014.11.024

Maithel, S. (2009). Biomass Energy, Resource Assessment Handbook. Asian and Pacific Centre for Transfer of Technology (APCTT). Economic and Social Commission for Asia and the Pacific (ESCAP).

Maity, S. K. (2014). Opportunities, recent trends and challenges of integrated biorefinery: part I. Renewable and Sustainable Energy Reviews, 43, 1427-1445. https://doi.org/10.1016/j.rser.2014.11.092 
Mandegari, M. A., Farzad, S. and Görgens, J. F. (2017). Recent trends on techno-economic assessment (TEA) of sugarcane biorefineries. Biofuel Research Journal, 4(3), 704-712. https://doi.org/10.18331/BRJ2017.4.3.7

Maneffa, A., Priecel, P. and Lopez-Sanchez, J. A. (2016). Biomass - Derived Renewable Aromatics: Selective Routes and Outlook for $\mathrm{p}$ - Xylene Commercialisation. ChemSusChem, 9(19), 2736-2748. https://doi.org/10.1002/ cssc. 201600605

Molton, P. M., Fassbender, A. G., Brown, M. D. (1986). STORS: The Sludge-to-Oil Reactor System; Report No. EPA/600/S286/034. Cincinnati, OH, USA: U.S. Environmental Protection Agency (EPA).

Morales, G., Iglesias, J. and Melero, J. A. (2020). Sustainable Catalytic Conversion of Biomass for the Production of Biofuels and Bioproducts. Catalysts, 10, 581. https://doi.org/10.3390/catal10050581

Morales-Delarosa, S. and Campos-Martin, J. M. (2014) Catalytic processes and catalyst development in biorefining. Wood head Publishing Limited. https://doi.org/10.1533/ 9780857097385.1.152

Mørup, A. J., Becker, J., Christensen, P. S., Houlberg, K., Lappa, E., Klemmer, M., Madsen, R. B., Glasius, M. and Iversen, B. B. (2015). Construction and Commissioning of a Continuous Reactor for Hydrothermal Liquefaction. Industrial \& Engineering Chemistry Research, 54(22), 59355947. https://doi.org/10.1021/acs.iecr.5b00683

Muniru, O. S., Ezeanyanaso, C. S., Fagbemigun, T. K., Akubueze, E. U., Oyewole, A. O., Okunola, O. J., Asieba, G. Shifatu, A. O., CIgwe, C. and Elemo, G. N. (2016). Valorization of biodiesel production: Focus on crude glycerin refining/purification. Journal of Scientific Research \& Reports, 11(5), 1-8. https://doi.org/10.9734/JSRR/ 2016/27982

OECD (2019). OECD-FAO agricultural outlook 2019-2028. Biofuels, pp. 9. https://doi.org/10.1787/agr_outlook-2019en

Ogunwole, O. A. (2012). Production of Biodiesel from Jatropha Oil (Curcas Oil). Research Journal of Chemical Sciences, 2(11), 30-33.

Onay, O. and Kockar, O. M. (2008). Slow, fast and flash pyrolysis of rapeseed. Renewable Energy, 28(15), 24172433. https://doi.org/10.1016/S0960-1481(03)00137-X

Paasikallio, V., Kalogiannis, K., Lappas, A., Lehto, J. and Lehtonen, J. (2016). Catalytic Fast Pyrolysis: Influencing Bio-Oil Quality with the Catalyst-to-Biomass Ratio. Energy Technology, 5(1), 94-103. https://doi.org/10.1002/ente. 201600094

Paasikallio, V., Lindfors, C., Kuoppala, E., Solantausta, Y., Oasmaa, A., Lehto, J. and Lehtonen, J. (2014). Product quality and catalyst deactivation in a four day catalytic fast pyrolysis production run. Green Chemistry, 16(7), 3549. https://doi.org/10.1039/C4GC00571F

Parasnis, A. (2010). Applications of Pyrolysis and Gasification - The Best from Waste. Sustainable Solid Waste Management, Kolkata.
Pedersen, T. H., Hansen, N. H., Pérez, O. M., Villamar Cabezas, D. E. and Rosendahl, L. A. (2017). Modeling and Analysis: Renewable hydrocarbon fuels from hydrothermal liquefaction: A techno-economic analysis. Biofuels, Bioproducts \& Biorefining, 12(2), 213-223. https://doi.org/10.1002/bbb.1831

Pfeifer, C., Rauch, R. and Hofbauer, H. (2004). In-bed catalytic tar reduction in a dual fluidized bed biomass steam gasifier. Industrial \& Engineering Chemistry Research, 43, 1634-1640. https://doi.org/10.1021/ie030742b

Pfitzer, C., Dahmen, N., Tröger, N., Weirich, F., Saucer, J., Günther, A. and Müller-Hagedorn, M. (2016). Fast Pyrolysis of Wheat Straw in the Bioliq Pilot Plant. Energy Fuels, 30(10), 8047-8054. https://doi.org/10.1021/acs.energy fuels.6b01412

Rahman, Md. M., Liu, R. and Cai, J. (2018). Catalytic fast pyrolysis of biomass over zeolites for high quality bio-oil A review. Fuel Processing Technology, 180, 32-46. https://doi.org/10.1016/j.fuproc.2018.08.002

Ralph, E. H. S., Warren, M., Jack, N. S. and Michael, T. (2010). Bioresource Technology: An overview of second generation biofuel technologies. Bioresource Technology, 101, 1570-1580. https://doi.org/10.1016/j.biortech2009.11. 046

Reif, P., Rosenthal, H. and Rose, M. (2020). Biomass-Derived Aromatics by Solid Acid-Catalyzed Aldol Condensation of Alkyl Methyl Ketone. Advanced Sustainable Systems, 4(10), 1900150. https://doi.org/10.1002/adsu.201900150

REN21. (2009). Renewable global status report. Available at: https://www.ren21.net/Portals/0/documents/activities/gsr /RE_GSR_2009_Update.pdf

Robinson, A. M., Hensley, J. E. and Will, J. (2016). Bifunctional catalysts for upgrading of biomass-derived oxygenates: A review. ACS Catalysis, 6(8), 5026-5043. https://doi.org/10.1021/acscatal.6b00923

Roland, A. L. and Jean-Michel, L. (2013). From first- to thirdgeneration biofuels: Challenges of producing a commodity from a biomass of increasing complexity. Animal Frontiers, 3(2), 6-11. https://doi.org/10.2527/af.2013-0010

Rößiger, B., Unkelbach, G. and Pufky-Heinrich, D. (2018). Base-Catalyzed Depolymerization of Lignin: History, Challenges and Perspectives. Intech open science. https://doi.org/10.5772/intechopen.72964

Rostrup-Nielsen, J. R. (2005). Making fuels from biomass. Science, 308, 1421-1422. https://doi.org/10.1126/ science. 1113354

Rubin, E. M. (2008). Genomics of cellulosic biofuels. Nature, 454, 841-845. https://doi.org/10.1038/nature07190

Safdari, M.-S., Amini, E., Weise, D. R. and Fletcher, T. H. (2019). Heating rate and temperature effect on pyrolysis products from live wildland fuels. Fuel, 2019(242), 295-304. https://doi.org/10.1016/j.fuel.2019.01.040 
Saifuddin, N., Refal, H. and Kumaran, P. (2014). Rapid Purification of Glycerol by-product from Biodiesel Production through Combined Process of Microwave Assisted Acidification and Adsorption via Chitosan Immobilized with Yeast. Research Journal of Applied Sciences, Engineering and Technology, 7(3), 593-602. https://doi.org/10.19026/rjaset.7.295

Serrano-Ruiz, J. C. and Dumesic, J. A. (2011). Catalytic routes for the conversion of biomass into liquid hydrocarbon transportation fuels. Energy \& Environmental Science, 2011(4), 83-99. https://doi.org/10.1039/C0EE00436G

Song, Y., Mobley, J. K., Motagamwala, A. H., Isaac, M., Dumesic, J. A., Ralph, J., Lee, A. F., Wilson, K. and Crocker, M. (2018). Gold catalyzed conversion of lignin to low molecular weight aromatics. Chemical Science, 9, 81278133. https://do.org/10.1039/c8sc03208d

Suesse, A. R., Norton, G. A. and Van Leeuwen, J. (2016). PilotScale Continuous-Flow Hydrothermal Liquefaction of Filamentous Fungi. Energy Fuels, 30, 7379-7386. https://doi.org/10.1021/acs.energyfuels.6b01229

Taarning, E., Osmundsen, C. M., Yang, X., Voss, B., Andersen, S. I. and Christensen, C. H. (2011). Zeolite-catalyzed biomass conversion to fuels and chemicals. Energy \& Environmental Science, 4(3), 793-804. https://doi.org/ 10.1039/C004518G

Thigpen, P. L. and Berry, W. L., Jr. (1982). Liquid fuels from wood by continuous operation of the Albany, Oregon biomass liquefaction facility. In Proceedings of the Energy from Biomass and Wastes VI: Symposium, Lake Buena Vista, FL, USA, pp. 1057-1095.

Toor, S. S., Rosendahl, L. and Rudolf, A. (2011). Hydrothermal liquefaction of biomass: A review of subcritical water technologies. Energy, 36, 2328-2342. https://doi.org/ 10.1016/j.energy.2011.03.013

Ubando, A. T., Rivera, D. R., Chen, W.-H. and Culaba, A. B. (2019). A comprehensive review of life cycle assessment (LCA) of microalgal and lignocellulosic bioenergy products from thermo-chemical processes. Bioresource Technology, 291, 121837. https://doi.org/10.1016/j.biortech.2019. 121837

Umenweke, Great. (2020) Advancements in Biorefinery Processing. Scientific Journal of Research \& Reviews, 2(5), SJRR.MS.ID.000548.

https://doi.org/10.33552/SJRR.2020.02.000548

Von Wedel, R. (1999). Technical handbook for marine biodiesel in recreational boats. Prepared for National Renewable Energy Laboratory, US Department of Energy, Subcontract No. ACG7-16688-01 under Prime Contract No. DE-AC36$83 \mathrm{CH} 10093$.
Watanabe, Y., Shimada, Y., Sugihara, A. and Tominaga, Y. (2001). Enzymatic conversion of waste edible oil to biodiesel fuel in a fixed bed bioreactor. Journal of the American Oil Chemists' Society, 78(2), 703-707. https://doi.org/10.1007/s11746-001-0329-5

World Bioenergy Association. (June, 2015). Available at: http://www.worldbioenergy.org/

World Energy Council, Resources 2016 Summary, 2016. Available at: www.worldenergy.org

Yamakawa, C. K., Qin, F. and Mussatto, S. I. (2018). Biomass and Energy: Advances and opportunities in biomass conversion technologies and biorefineries for the development of a bio-based economy. Biomass and Bioenergy, 119, 54-60. https://doi.org/10.1016/j.biombioe. 2018.09.007

Yaman, S. (2004). Pyrolysis of biomass to produce fuels and chemical feedstocks. Energy Conversion and Management, 45(5), 651-671. https://doi.org/10.1016/S0196-8904(03) 00177-8

Yaning, Z., Yunlei, C., Paul, C., Shiyu, L., Nan, Z., Kuan, D., Liangliang, F., Peng, P., Min, M., Yangling, C., Yunpu, W., Yiqin, W., Yuhuan, L., Bingxi, L. and Roger, R. (2019). Chapter 14 - Gasification Technologies and Their Energy Potentials. In Sustainable Resource Recovery and Zero Waste Approaches (pp 193-206). https://doi.org/10.1016/B978-0444-64200-4.00014-1

Ye, Y., Zhang, Y., Fan, J. and Chang, J. (2012). Selective production of 4-ethylphenolics from lignin via mild hydrogenolysis. Bioresource Technology, 118, 648-651. https://doi.org/10.1016/j.biortech.2012.05.127

Zhai, Y., Li, C., Xu, G., Ma, Y., Liu, X. and Zhang, Y. (2017). Depolymerization of lignin via a nonprecious Ni-Fe alloy catalyst supported on activated carbon. Green Chemistry, 19, 1895-1903. https://doi.org/10.1039/C7GC00149E

Zhang, B., Tang, X., Li, X., Xu, Y. and Shen, W. (2007) Hydrogen production from steam reforming of ethanol and glycerol over ceria-supported metal catalysts. International Journal of Hydrogen Energy, 32(13), 2367-2373. https://doi.org/10.1016/j.ijhydene.2006.11.003

Zhang, Y., Dube, M. A., McLean, D. D. and Kates, M. (2003). Biodiesel production from waste cooking oil: 2. Economic assessment and sensitivity analysis. Bioresource Technology, 90(3), 229-240. https://doi.org/10.1016/S09608524(03)00150-0

Zhu, Z., Rosendahl, L., Toor, S. S., Yu, D. and Chen, G. (2015b). Hydrothermal liquefaction of barley straw to bio-crude oil: Effects of reaction temperature and aqueous phase recirculation. Applied Energy, 137, 183-192. https://doi.org/10.1016/j.apenergy.2014.10.005

Zhu, Z., Toor, S. S., Rosendahl, L., Yu, D. and Chen, G. (2015a). Influence of alkali catalyst on product yield and properties via hydrothermal liquefaction of barley straw. Energy, 80, 284-292. https://doi.org/10.1016/j.energy.2014.11.071 